\title{
The Demand and Effects of Accountability and Efficient Utilization of Resources by Donors of Local Non- Governmental Organisations (NGOs): A Qualitative Assessment of Some Selected NGOs in the Central Region of Ghana
}

\author{
Emmanuel Abeku Essel, PhD Student \\ National University of Public Service, Budapest, Hungary
}

Doi:10.19044/esj.2021.v17n32p21

Submitted: 01 September 2021

Accepted: 23 September 2021

Published: 30 September 2021
Copyright 2021 Author(s)

Under Creative Commons BY-NC-ND

4.0 OPEN ACCESS

Cite As:

Abeku Essel E. (2021). The Demand and Effects of Accountability and Efficient Utilization of Resources by Donors of Local Non-Governmental Organisations (NGOS): A Qualitative Assessment of Some Selected NGOS in the Central Region of Ghana. European Scientific Journal, ESJ, 17 (32), 21. https://doi.org/10.19044/esj.2021.v17n32p21

\section{Abstract}

Accountability is a critical notion in social policy because it underpins a government or private actor's efforts to deliver services to client groups and execute social programs. Over the last few decades, Non-Governmental Organizations (NGOs) have become an integral part of most countries' organizational landscape which plays an intermediary role between donors and beneficiaries. To ensure the efficient utilization of resources, NGOs are required to be accountable to the two main stakeholders they serve: donors and beneficiaries. There are challenges in evaluating performance criteria, particularly when it comes to measurable effect indicators. The argument is that the impact of other variables on NGOs renders interpretative and strategic responsibility difficult. This article explains the forms and how accountability is practiced in Non-Governmental Organizations in Ghana. This paper focuses on exploring how accountability is influenced by the organizational missions and values. The study adopted an in-depth interpretive case study approach using two selected organizations in the Central Region of Ghana. Data was gathered by way of interviews and documentary review. In total, 10 interviews were conducted in the selected organizations. The study revealed that the accountability systems were both upward and downward towards donors. The 
study therefore proposes that donors should show a much greater commitment to accountability, and actively involve beneficiaries in the process of accountability in obtaining genuine benefits.

Keywords: Resource Utilization, Accountability, Auditing, Donors, Evaluation, Performance Measurement, Non-governmental organizations

\section{Introduction}

As a result of Ghana's social-policy reforms, sustainable social sectors and poverty alleviation have improved in the country. Areas where this has manifested include that of health, education, social security, housing, and other poverty alleviation initiatives (Nelson et al.,2013). In spite of this, rural communities are clearly underserved in terms of social services (Kim, 2013). The dominating sectors of health, education, and agriculture have failed to pay enough attention to rural poverty-alleviation programs (Kim, 2013). For example, according to the Ghana Statistical Service (2013), Ghana is assessed to be a lower-middle-income nation. To combat poverty, a number of social intervention programs such as Livelihood Empowerment Against Poverty (LEAP), the Capitation Grant, and the School Feeding Programme have been established including the "Shared Growth and Development" which is the government's current policy paper and strategy for poverty reduction. Malnutrition, poor health, illiteracy and insecurity, among others, define the living circumstances and well-being of most Ghanaians in spite of the many assistant programs and intervention plans put in place by the government. These problems are a strong indicator of Ghana's underdevelopment as observed by Ghana Living Survey (2014). In addition to the efforts of the government to guarantee a strong socio-economic growth, several nongovernmental organizations have emerged and are playing various roles to help ameliorate the burden of the people. However, it is still debated whether or not non-governmental organizations have a positive impact on the development of developing economies such as Ghana (Boelhe, 2010; Clarke \& Jennings, 2008; Woolnough, 2013). Ghanaians depend on NGOs for their survival as a result of social intervention projects carried out in deprived communities, even though they are well aware of their contribution to socioeconomic development in rural communities (Adei, 2015; Armah, et al., 2010). A few examples of services provided by NGOs include education, sanitation and health care, agricultural, environmental protection as well as training in vocational skills, food security, and capability (Ghana Statistical Services, 2013).

According to Gray et al. (2006), the notion of a non-governmental organization is often described in terms of the 'negative space' of "what they are not." On the other hand, Unerman and O'Dwyer (2006a) noted that the 
definition of a non-governmental organization is controversial and complicated in part due to the constraints under which these organizations operate. Unerman and O'Dwyer (2006a) concurred that the ambiguity of the term "NGO" aids in communicating the importance of these organizations and their operations. According to Banks and Hulme (2012), "non-governmental organizations" (NGOs) are often meant to supplement public social goods in terms of poverty reduction and may be able to contribute to development advancement. According to Gray et al. (2006), "considerable diversity" in terms of size and function, as well as perspectives, norms, strategy, and tactics, is to blame for the difficulties in defining non-governmental organizations (Awio et al., 2011). According to Edwards (2000), development-oriented NGOs' operations include humanitarian aid, as well as longer-term livelihood support programmes motivated by a desire for the good of humanity. This implies that non-governmental organizations (NGOs) working for development are often active participants in social development, particularly in poor countries, with the goal of improving the quality of life (Brown \& Kalegaonkar, 2002; Fowler, 2013). In other words, development-oriented NGOs, often referred to as social development organizations, may exist primarily to provide goods and services - directly or indirectly (Brinkerhoff et al., 2007).

In poor nations, there are two primary kinds of development-oriented NGOs: secular and religious (Woolnough, 2013; Ferris, 2005). According to Woolnough (2013), "development" is a means of assisting people in becoming "less materially impoverished" (economic empowerment). Following financial and resource support, a bureaucratic set of development goals and strategic field choices is implemented (Woolnough, 2011). According to Woolnough $(2011,2013)$, sustainable development is the only focus of secular non-profit organization's programs and operations. Nonetheless, secular NGOs' primary goal for development may well be to alleviate poverty, for Community and Faith Based Organizations (CFBOs). Success entails not only addressing material poverty, but also striking a balance between spiritual and economic dimensions of life (Bradley, 2009).

Accountability is a critical notion in social policy because it underpins a government or private actor's efforts to deliver services to client groups and execute social programs. In the public and private sectors, it is the "magic wand" for justice, democracy, ethical governance, cost efficiency, and efficient service delivery which have become popular over the last three decades (Ebrahim \&Weisband, 2007). The popularity of accountability has resulted in a strong desire for accountability in policies and processes in both the public and commercial sectors (Behn, 2001). While this need has expressed itself in Western democracies, it has also manifested itself in additional or increased record-keeping, reporting, and information 
dissemination requirements for public sector organizations (Mulgan, 2003). A 'principal' or 'one who holds responsibility' is often used in conjunction with the fundamental notion of responsibility (Gray et al., 1997; Stewart, 1984). This information is sent to the 'principal' via an 'agent' who is 'responsible' (Stewart, 1984). When resources or responsibilities are moved, matching 'expectations' accompany the transfer (Gray et al., 1996; Mulgan, 2000). According to Mulgan (2000), a conventional accountability link includes social interactions and a trade. This is so because a report is "given to some other organization or individual requiring social engagement and exchange". According to Mulgan (2000), duty is concerned with the external world. According to this interpretation, accountability may imply both the duty to act and the requirement to account for one's conduct (Gray et al., 1996).

According to O'Dwyer and Unerman (2008), nongovernmental groups exercise influence and impose obligations, and the accountability process is institutionalized via specified reporting criteria, which they found to be accurate. In this context, a well-established set of expectations and norms serves as the anchor for accountability connections (O'Dwyer \& Unerman, 2008). When it comes to formal duty, there are specific behaviors and duties that are expected from those entrusted with such responsibilities (Laughlin, 2004). According to Ebrahim (2009), 'power' processes have a hierarchical structure that incorporates governance (i.e., based on law), economic resources, and professional standards. This has resulted in the development of frameworks outlining the accountability process (Ebrahim, 2009). A hierarchical structure is used to define the relationship between the superior (the accountee) and the subordinate (the accountant), which guarantees that funds are spent appropriately and in compliance with legal requirements. Llewellyn (2003) asserted that moral values are being repressed as a result of these systems' predominance of responsibility linkages. Roberts (1991) believes that informal connections are more essential than traditional accountability standards since job descriptions are ambiguous and unclear. Additionally, both parties may get engaged since both sides desire a strong working relationship (Robert, 1991). According to Gray et al. (2006), formal connections are less important than the perception of a close relationship.

The accountability of NGOs is complex as a result of the environment in which NGOs operate (Agyemang et al., 2009; A wio et al., 2011). NGOs act as intermediary organizations, and are faced with multiple demands from stakeholders (Agyemang et al., 2009; Jordan \& van Tuijl, 2006; O’Dwyer, 2007). Governments and donor agencies in affluent nations often fund nongovernmental organizations (NGOs) that provide local services. As a consequence of their local operations, NGOs and International NonGovernmental Organizations (INGOs) "function as a conduit between international donors and local beneficiaries" (Agyemang et al., 2009). Non- 
governmental organizations (NGOs) engage with stakeholders to develop accountability procedures for complex social projects (Alex \& Wilford, 2010). According to Alex and Wilford (2010), International non-governmental organizations (INGOs) are needed to negotiate with donors and plan future activities in cooperation with local partners. Indeed, INGOs are held accountable for assisting these NGOs in figuring out how to manage these complex webs of relationships. The primary challenge for a non-governmental organization is organizing and communicating with a diverse range of stakeholder groups, some of whom have little influence over them but are immediately affected by their operations, and others who wield considerable power but are geographically dispersed (Alex \& Wilford, 2010). Additionally, as NGOs grow in size and establish their own internal systems, politics, and bureaucracy, the problem gets worse. These issues of accountability for NGOs are well-documented in the literature. The literature distinguishes many distinct types of accountabilities for non-governmental organizations (Bendell, 2006; Baur \& Schmitz, 2012). Donors, governments, and foundations utilize accountability processes to exercise influence on the nongovernmental organization that is carrying out the project, resulting in upward accountability (LIoyd, 2005; Andrews, 2014). Indeed, non-governmental organizations (NGOs) are a reaction to accountability requirements. While NGOs are accountable to their beneficiaries, who are often weaker in their power and accountability connections with NGOs, they do hold non-economic resources such as "knowledge" that are critical to the organizations' purpose and vision fulfillment (Baur \& Schmitz, 2012; Andrews, 2014).

In recent years, nongovernmental organizations (NGOs) in Ghana have been attacked for their lack of accountability, in part, as a result of a succession of high-profile scandals undermining public confidence in nonprofit organizations, and as a result of NGOs' rapid growth throughout the country (Gibelman \& Gelman, 2001; Young et al., 1996). Despite a dearth of empirical data, donors think that NGOs are more cost efficient than governments at delivering fundamental social services, this is because they are better equipped to serve the poor, and are important participants in democratic processes (Edwards \& Hulme, 1996; Mackintosh, 1992). As Riddel (1999) pointed out, non-governmental organizations (NGOs) most often overplay their claims of legitimacy based on a belief in value-driven organizations rather than real monitoring and evaluation of their achievements. As a result, a growing number of practitioners and academics in the sector are questioning these assumptions and arguing that a more realistic approach to accountability problems is needed instead of viewing NGOs as "magic bullets" (Edwards \& Hulme, 1996; Najam, 1996). As a consequence of resource disparities, concerns regarding the donor accountability of NGOs are typically focused upon expensive funding 
conditions or onerous reporting requirements. Accountability measures, such as yearly project reports and financial records, are used by NGOs to raise money by publicizing their programmes and activities, thus, one is not far from right in alluding to the fact that NGOs rely on donors for funding of their various projects and development of their reputations too as well (Ebrahim, 2002; Hudock, 1999; Perera, 1997). There is a lot of information regarding accountability that can be gleaned from resource dependency studies, particularly in terms of how companies function and relate with their shareholders. What is missing from much of the debate on accountability is an integrated look at how organizations deal with multiple and sometimes competing accountability demands.

Global accountability in the context of non-profits involves the assignment of responsibility among the various stakeholders who contribute to the organization's growth and development. A duty connection exists with strong stakeholders; authority and ownership control that emphasizes the value of resources and economic advantages, while also being affected by legal and bureaucratic processes.

The accountability relationships upward are what dominate the NGO accountability literature, and is given priority because it emphasizes NGOs' need for economic resources and the monitoring role of the funders (Agyemang et al., 2009). Financial resources as a "connector" may be used by officers to assess the performance of comprehensive responsibility in respect to "powerful" stakeholders or "less powerful" stakeholders. Therefore, accountability links are seen as having either an objective sense of control aiming towards hierarchical upward responsibility or a subjective reality intended to benefit groups of stakeholders (Llewelyn, 2003). To ensure that their organization's objectives and the "development" goal of poverty reduction are met, non-governmental organization executives are increasingly being held responsible to a broad range of stakeholders. The major questions that remain unanswered is whether, in the context of NGOs in the country and particularly in the central region where it is being stated that poverty is on the ascendency, holistic accountability relationships in any way influence the achievement of organizational missions and the development mission of poverty alleviation. Thus, the need to seek to understand ways by which 'accountability' might matter and help achieve development missions in the NGOs. This means examining the ways in which "accountability" may assist non-governmental groups to accomplish their development goals as opined by O'Dwyer and Unerman (2008). It also involves the use of holistic accountability as a basis for the conversation in order to better understand the officers' perceptions of accountability links, and how this impacted their ability to achieve their goals. 


\section{Objectives}

The goal of this study was to examine the nature of accountability relationships of some selected NGO. However, Global Family Network Ghana (GFNG) and Network for Rural Human Resource Development and Enterprise Initiative are two NGOs based in the central region of Ghana and are the two organizations that made time and availed themselves for the study. The other aim was to explore how accountability is influenced by the organizational missions and values.

\section{Methodological Approach}

The information for this article was compiled using a mix of field interviews and desk research. The researcher collected qualitative data through in-depth interviews with 10 respondents from two NGOs (Global Family Network Ghana and Network for Rural Human Resource Development and Enterprise Initiative) using the purposive sample technique. The purpose of using the two case organizations was not for comparison, but rather to draw out common trends and themes for better understanding of how an NGO can be accountable and also deal with the associated challenges. This allowed the officers to share their personal experiences within the context of Ghana. The author performed almost all face-to-face interviews, ensuring consistency in queries and probing depth. A criterion in the selection of the examples was that they had employees who were willing to participate and explain the organizational accountability measures, as well as solid archival documents to back up their assertions. In order to extend and strengthen the researcher's understanding of key issues addressed during interview discussions, the researcher examined historical records, particularly mission statements and strategic plans for projects. The researcher was also granted official access to review annual financial reports and other documentary proof (daily financial expenditures, allowances for field officers and officers, per diem for travelling, etc.) essential to the organization's activities, and practices inspection after being fully incorporated into the NGO's operations. These documents were reviewed in tandem with the interviews that were conducted to ascertain the effectiveness of donors' accountabilities on the two NGOs selected for the study. This was further supplemented by the data gathered via interviews and video analysis with a monitoring report on contract-funded projects, management responses to external evaluations, and extensive archival materials (internal documents covering budgets, publicity material, and reporting requirements from funders). These articles were useful since they confirmed many of the arguments stated during the interviews. The papers gathered from the non-governmental organizations (NGOs) were combined and examined to see how accountability is perceived and executed. The interviews were transcribed verbatim as suggested by Miles and 
Huberman (1994). After the transcription of the interviews, the researcher read through carefully to check for inconsistencies as analytic methods, reflexive analysis, and coding were used.

\section{Discussions}

\section{The Case for Ghana: NGOs Role in Poverty Alleviation}

Prior to the formation of NGOs, Community-Based Organizations (CBOs) existed and met the needs of the communities they served (Bob-Millar \& Bob-Millar, 2007). It was established on the basis of the 'Nnoboa' (in the native Akan language), a technique of self-help, which was developed in Nigeria. 'Self-help' was a pre-colonial form of aid inspired by culture and used by indigenous Ghanaians. Members of the community would support one another's agricultural activities by alternating assistance to subsistence farmers in remote farming regions (Armah et al., 2010). CBOs in Ghana have historically been seen as non-profit organizations due to the expansion of duties and efforts to aid in the country's socio-economic growth, and its poverty alleviation approaches (Casely-Hayford \& Hartwell, 2010). According to the Ministry of Gender and Social Protection's NGO Desk, about 3,000 international-based NGOs operate in Ghana, with offices located across the nation as recorded by the Government of Ghana (2015). Local Organizations, Faith-Based Organizations, Community-Based Organizations, Foreign Aid Agencies, and other kinds of organizations constitute this category as recorded by the Government of Ghana (2015). Ghana has a number of organizations, all of which operate in each of the country's sixteen administrative districts. Nonetheless, Ghana's government is likely to eradicate poverty entirely from all areas (Bawole \& Langnel, 2016). Despite government attempts to assist rural poverty reduction initiatives, the local NGO sector has remained steadfast in its support for the development objective (Casely-Hayford \& Hartwell, 2010; Rahaman et al., 2007). This implies that NGOs play a significant role in the expansion of Ghana's social sector and economic development, with the goal of relieving the country's long-term poverty and socioeconomic problems (Agyemang et al., 2009; Lambert, 2014). Local non-governmental organizations are mostly supported by aid programmes and foreign funding, which are usually seen as beneficial to socio-economic development (Rahaman, 2010; Agyemang et al., 2017).

Ghana's NGOs have developed a hyper-awareness of their foreign donors, which include the World Bank and the International Monetary Fund (IMF) (Rahaman, 2010). Ghana has also suffered as a result of the global financial crisis with decreased NGO funding. Even though Ghana used to receive $\$ 1.8$ billion in foreign assistance yearly until 2011, this funding has decreased considerably (OECD, 2012). Without a doubt, NGO funding schemes have been affected, resulting in a negative effect on poverty reduction 
initiatives, including the Millennium Development Goal's (MDGs) that depend on local and international NGOs as reported by MDG National Report, (2014). While accountability of donor aids may be instrumental in the pursuit of development in developing countries, attention has not been given to specific group of NGO levels to know whether this influences the achievement of missions of recipient organizations. This is why O'Dwyer and Unerman (2008) commented that in order to understand accountability, "a study should be made in a specific setting".

\section{The Influence of NGOs in the Development Field in Ghana}

Through an officer interview discussion regarding accountability connections and responsibility-giving processes, words like trust, stewardship, and personal values were often used. Officers, for example, said that management has been effective in relying on the faith of its funders (sponsors and donors), who provide management with financial means to work with. Officers felt that using money received from sponsors to support developmental projects in their operational areas involved personal moral responsibility and responsibilities.

"All money collected is used to improve child welfare and poverty reduction. We are aware that we may be held accountable" (Director A).

This shows that the principles of the Global Family Network Ghana (GFNG) and the Network for Rural Human Resource Development and Enterprise Initiative seem to influence how activities are carried out as well as officers' views about the usage of financial resources for projects. Officers are aware of this and the controls and procedures put in place ensure that financial resources are used wisely. However, the interviews revealed that the staff is guided by their values when it comes to smart money management.

"Certainly, we do things that distinguish ourselves from other companies. We stick to our core principles of being real and honest. I am also a pastor, and you are aware of what we stand for in God's sight, such as love for one another and humanity" (Director B).

As organizational core values, integrity, stewardship, and dignity give the impression that officers are working on behalf of God to help children, but it also shows that they are accountable for various actions for the use of organizational resources as a result of their stewardship values, which are described above. Officers indicated that they held themselves more accountable when questioned about their own personal duty and moral commitment to provide honest and fair accountability for their actions. The contribution to development made by GFNG and the Network for Rural Human Resource Development and Enterprise Initiative is not only a clear moral commitment to a "good cause," but it also ensures that the resources entrusted to officers for this purpose are well-spent. It's worth noting that 
officials' personal values are enhanced by the trust that financial resource sponsors have put in them. When a sponsor makes a contribution, there was a clear understanding that the authorities would carry out the stated goal.

\section{Existing Practice of Beneficiary Accountability}

Beneficiary accountability performance is strongly linked to social connections between NGOs' focal parties and beneficiaries (O'Leary, 2016). The study revealed that the intensity of transactions and degree of closeness between NGOs' representatives and beneficiaries affect the accountability systems that the NGOs discharge. According to a detailed examination of the documents published by Global Family Network Ghana (GFNG) and Network for Rural Human Resource Development and Enterprise Initiative, they have to proactively find out the cases through searching and discharge accountability through their own mechanism in most cases. It is not a result of demand. This is consistent with the findings of O'Dwyer and Unerman (2008), who discovered that beneficiaries of NGOs cannot demand measures from them in the same way that corporate shareholders may. According to the findings of the analysis, beneficiary accountability in Global Family Network Ghana (GFNG) and the Network for Rural Human Resource Development and Enterprise Initiative can be divided into three categories: delivery of provisions and services, disclosure of financial statements, and empowerment of beneficiaries to be self-sufficient. Among these three types, the first and third are particularly visible in the beneficiary accountability practices of Global Family Network Ghana (GFNG) and Network for Rural Human Resource Development and Enterprise Initiative.

The beneficiary accountability system of Global Family Network Ghana (GFNG) and Network for Rural Human Resource Development and Enterprise Initiative adheres to the principles of simplicity, involvement, and close communication. To stay in touch with the grassroots beneficiaries, they use a network structure to reach out to them on a regular basis. Global Family Network Ghana (GFNG) and the Network for Rural Human Resource Development and Enterprise Initiative produce various publications such as yearly reports, newspaper articles, and quarterly bulletins to fulfill beneficiary responsibility. They also reach out to lower-level stakeholders by organizing various cultural programs in cooperation with local governments. These programs assist to increase awareness in communities. Global Family Network Ghana (GFNG) and the Network for Rural Human Resource Development and Enterprise Initiative bring to light certain issues impacting communities and children in order to fulfill their responsibility to the downstream stakeholders. 


\section{Mechanisms of Accountability}

For example, organizations that rely on external funding may be 'forced' to comply with particular financial reporting requirements, publish information publicly or to specific recipients, and implement transparency measures. Contributors to the Global Family Network Ghana (GFNG) and the Network for Rural Human Resource Development and Enterprise Initiative (NRHRDEI) are sometimes referred to as "donors." Funding for Global Family Network Ghana (GFNG) and NRHDEI is reliant on donors, according to the research by Froelich (1999). For future financing, survival, and growth, the two NGOs must continually accept the latter's (funders') demands. Donors are seen 'pushing' certain kinds of reporting (financial and non-financial), review meetings, publication of specific information, and involvement (although restricted) of certain community representatives in the organization's operations. Funders may also 'force through' accounting and reporting practices on projects with little or no involvement from organizations (Global Family Network Ghana (GFNG) and Network for Rural Human Resource Development and Enterprise Initiative). In other words, if Global Family Network Ghana (GFNG) and Network for Rural Human Resource Development and Enterprise Initiative do not accept or adhere to particular standards or processes, donors may postpone or even withdraw funds. Similar findings have been reported in the literature for other developing country settings. For example, Assad and Goddard's (2010) study of stakeholders' involvement in the accounting practices of two Tanzanian NGOs concluded that donors are the most relevant stakeholders due to their ability to withhold resources from NGOs. As a result, these academics argue for a reduction in donor control over NGOs, saying that funders, after all, depend on NGOs to carry out their objectives. While this rationale applies to the NGO industry as a whole, it does not seem to apply to the isolated NGO. In Ghana's Central Region, where Global Family Network Ghana (GFNG) and the Network for Rural Human Resource Development and Enterprise Initiative coexist with hundreds of other non-governmental organizations (NGOs), the organizations are seen as a drop in a sea of hundreds. As a result, it is thought to be at the donors "'mercy." As a result, if Global Family Network Ghana (GFNG) and the Network for Rural Human Resource Development \& Enterprise Initiative do not listen to and follow their advice, they will be phased out and replaced by other competing NGOs. Based on Mitchell et al. (1997) stakeholder's framework, it is tempting to argue that donors are definitive stakeholders in the context of Global Family Network Ghana (GFNG) and Network for Rural Human Resource Development \& Enterprise Initiative (NRHRDEI). Hence, this is because they appear to have power, legitimacy, and urgent claims (via the provision of critical resources that donors can withhold). 
According to some scholars, upward accountability hinders collaborative and open learning and sharing, thereby limiting the capacity of non-governmental organizations (NGOs) to serve as catalysts for social change (Dixon et al., 2006; Ebrahim, 2003b; 2005). Furthermore, the research claims that Global Family Network Ghana (GFNG) and the Network for Rural Human Resource Development \& Enterprise Initiative (NRHRDEI) altered their reporting formats, audits, degree of transparency, and word count to meet donor criteria. The bulk of the modifications, according to Global Family Network Ghana and the Network for Rural Human Resource Development and Enterprise Initiative, were made to meet donor expectations. Ebrahim (2003) argued that, in addition to mandates, yearly reports, standards, financial reporting obligations, and laws, forced isomorphism may be driven by legal or technological concerns (Powell \& DiMaggio, 2012). Several studies have shown that donors, both domestic and foreign, have an impact on non-profit accounting procedures. Funders in Tanzania, according to Assad and Goddard (2010), have changed their accounting processes to account for NGO adoption. Global Family Network Ghana (GFNG) and the Network for Rural Human Resource Development and Enterprise Initiative (NRHRDEI) carry out a variety of audits to guarantee long-term resource availability. According to some academics, upward responsibility instills dread and anxiety in nongovernmental organization administration, since they must demonstrate 'success' (Ebrahim 2003a; Najam, 1996; Roberts, 1991). Alternate auditing schedules and standards were developed with the participation of GFNG and the Network for Rural Human Resource Development and Enterprise Initiative with various sponsors.

Despite the fact that they are only tangentially involved in the activities of Global Family Network Ghana and the Network for Rural Human Resource Development and Enterprise Initiative, the funders feel obliged to use forceful upward accountability techniques. Perhaps funders will continue to apply accountability measures in order to maintain complete control over non-profit operations, and because non-profits are ready to accept imposed restrictions without resistance. To ensure effective resource allocation, funders' involvement in the NGO accountability relationship necessitates the continuous presentation of an NGO's accountability credentials. As a result, Global Family Network Ghana (GFNG) and the Rural Human Resource Development and Enterprise Initiative (NRHRDEI) will always be required to follow donor guidelines. Assisting beneficiaries in making choices, increasing NGO efficiency, and encouraging openness and sustainability may all help to achieve balance (Unerman \& O'Dwyer, 2010). The findings indicated that crucial concepts or circumstances are required to comprehend the concept of responsibility. According to the findings, the accountability process should be open and seen as a fundamental value of the NGO, as well as a duty to 
stakeholders. Information given to stakeholders, including employees, should be essential, comprehensive, sufficient, and correct. The information should also be free-flowing and two-way, but neither those who give nor those who receive it should feel compelled to provide it. In general, the principles may be summarized as doing the right thing and telling others about it.

\section{Challenges of Ensuring Accountability}

The study found that while ensuring accountability to stakeholders was not a major challenge for NGOs, informants generally agreed that meeting staff demand for accountability, rendering account on ideology, knowledge, and skill for ensuring accountability, meeting beneficiaries demand for accountability, and collecting and reporting qualitative data were all slightly difficult. Furthermore, important informants shared their perspectives on how the organization might enhance its responsibility to its employees. First, NGOs may enhance employee responsibility by sharing important information about funding and spending with employees. Second, they may promote teamwork, strong interpersonal relationships among employees, and monthly reporting on planned activities and budgets as agreed upon by personnel. Third, NGOs may enhance their staff accountability by incorporating innovation and creativity into their operations and reacting to changes in their environment. However, the informants indicated that in order for the measures to be effective, the NGOs should create a work environment of transparency and openness by involving staff in decision making, improving formal and informal communication, and allowing more information flow from management to staff and from staff to management.

\section{Accountability Relationships within the Field}

Significant connections or relationship problems impacting NGOs, according to Kilby (2006), include determining who has the authority to hold others accountable and who is responsible for explanation and correction. Kilby (2006) goes on to say that power is dispersed in the development sector via NGO accountability relationships with partners and funders. Accountability linkages are strongly emphasized in key organizational strategy papers, such as the Field Programmes Manual and the Annual Report at Global Family Network Ghana (GFNG) and Network for Rural Human Resource Development and Enterprise Initiative.

"An accountability framework should be established to offer support and supervision for the project via the development of criteria and a defined procedure that ensures the best possible choices."

This means that accountability is intended to influence both the work of organizational officers and the way individual officers interact with people to whom they believe they are responsible in order to accomplish the purpose 
and objectives of the NGO's worldwide headquarters. Furthermore, it aids cops in making informed choices and attaining results. Reading the Annual Reports of the Global Family Network Ghana (GFNG) and the Network for Rural Human Resource Development and Enterprise Initiative offers more information on accountability, and how they support fieldwork in comparable ways. Words like "responsibility" and "we report to cover activities" emphasize the significance and presence of duty discharge to organizational field participants. In essence, there is a concept of authority and power processes that seem to persuade authorities to justify their acts, actions, or the reasons for certain activities. However, it may also relate to the parties' or stakeholders' capacity to handle money and other resources efficiently (Christensen \& Ebrahim, 2006). To put it in another way, officials from Global Family Network Ghana (GFNG) and the Network for Rural Human Resource Development and Enterprise Initiative seem to grasp how activities are carried out in accordance with program completion and set performance standards (Laughlin, 2008).

The following question was posed to key informants in order to determine the extent of responsibility by the NGOs in the research: "To whom and for what do you account as an organization?" The aim and underlying assumptions of these questions were to; (a) determine who the NGOs in the research were responsible to, and (b) determine what actions or reasons they were held accountable for. According to the findings of the research, organizations must answer the case to a variety of stakeholders. These include funders, the state (government), beneficiaries, employees, and other NGOs (peers) with whom they collaborate closely. This categorization of stakeholders to whom NGOs must account is analogous to the distinction between upward stakeholders - governments and foreign donors - and downward stakeholders - the beneficiaries whose interests they profess to seek and serve.

According to the Finance Directors of Global Family Network Ghana (GFNG) and Network for Rural Human Resource Development and Enterprise Initiative, the primary goal of reporting accountability to donors and sponsors is to ensure that the NGO's donors are satisfied with the NGO's obligation to report on projects with hierarchical upward accountability. The financial and physical results of the project are made public. According to O'Dwyer and Unerman (2008), hierarchical upward accountability connections impose a significant burden of justifying choices and actions to stakeholders who have influence over key resources. According to Bourdieu (1989), field occupiers depend on freely available resources for legitimacy (or usefulness) and authority. 


\section{Governmental Partnership with the NGOs}

Officers highlighted their connections with Ghana government sectors, including district assemblies (where the NGO operates) and some central government departments, as well as their reporting processes. Officers said that maintaining these connections is critical since no one agency can meet all of their needs. Officers emphasized how they often collaborate with government agencies, noting that their role is to supplement the government's development efforts. They see their donors/sponsors as entrusting them with this responsibility. Participants in the poll also said that their nongovernmental organizations (NGOs) could not be self-sufficient without a good working relationship with the government and its agencies, especially when operating in close proximity Gray et al. (2006). Respondents, on the other side, feel that contacts with the government may conflict with previously agreed-upon operating procedures with their donors/sponsors. This official, for example, highlighted "political" participation as a potential problem with the working processes of the Network for Rural Human Resource Development and Enterprise Initiative: "Our sponsor does not want to deal with the government." They have a policy of avoiding engaging with the government, anything political, and avoiding controversy." This observation relates to Bourdieu and Wacquant's (1992) assertion that there are two types of actors: "dominant" and "dominated". While the 'dominant' actors attempt to control and manage the field's current structure, the 'dominated' actors (despite holding a regulated position within a field) seek change in order to improve their positions (Golsorkhi et al., 2010).

However, the NGOs were responsible to the following government agencies: the Department of Social Welfare, the Internal Revenue Service, and the Registrar General Department. This is so because of the kinds of people they were dealing with, children and the vulnerable. The key informants said that they were responsible to the government because "as an NGO, there are legal criteria that the NGOs must meet in terms of registration (initial and periodic-renewal), financial management, audit, and annual report." They also said that it is the organizations' responsibility to inform the government about their actions and duties. Beneficiaries in this context refer to people who directly benefit from the services of non-governmental organizations, as well as their families and the communities from which they originate. They are made up of a diverse collection of individuals, including women and youth groups, children, and the district assembly. The Directors, Heads of Departments, and their subordinates make up the personnel here. Peers are other non-governmental organizations (NGOs) or development agencies that cooperate or work closely with the NGOs to accomplish a shared objective. With all of these stakeholders, the NGOs use a variety of ways to ensure that they are informed of the financial condition and operations of the 
organizations, as well as to enable them to express their opinions and requests. The findings in this section are consistent with O'Dwyer and Unerman (2008) claim that NGOs are accountable to donors for the resources they use and to beneficiaries for the effective delivery of goods and services, to peers for joint activity performance, to staff for meeting expectations, and to the government for compliance with regulations.

Aside from legal issues, there was a widespread notion that making friends with government officials and agencies would help a project run smoothly and successfully. As a consequence, participants say that interacting with and meeting with government agencies builds social connections, stressing that social interaction with the government and its agencies are a sure way to offer great services to beneficiaries. According to a Director, informal discussions with politicians and government officials have proved successful in their operations. A strong working connection and informal interaction with key politicians or government officials, in the Director's view, are helpful to a smooth work process. According to the director, it "ensures we are also acknowledged in government circles."

\section{Increasing Non-Governmental Organization Accountability}

There are many reasons for non-governmental organizations (NGOs) to embrace the subject of responsibility. The first is to avoid solutions that are costly and do not meet organizational or network learning needs. The second step is to respond to stakeholders who are impacted by NGO decisions. The third aim is to improve outcomes, while the fourth aim is to strengthen nongovernmental organizations (NGOs') involvement in civil society (where NGOs are just one form of association). NGOs whose operations are based on strong principles must publicly announce their goals in order to attract more supporters and protect themselves against political attacks. These concerns lead to the need for accountability systems other than those often proposed by donors. Understanding that responsibility is a socially produced concept that varies by culture may aid in improving NGO accountability. When addressing the obligations and rights of active non-governmental organizations, it is critical to analyze the rights and responsibilities that create societal norms within that context. Assessment and evaluation are, for the most part, effective kinds of accountability systems since they may contribute to organizational learning when done correctly. However, if a donor is too stringent in defining acceptable forms of evaluation and assessment, an NGO's opportunity to learn may be lost. Non-governmental organizations (NGOs) should take the lead in securing financing for assessment and evaluation, so that they may develop their own approach. Funders may assist the sector by providing resources for non-governmental organizations to develop assessment processes without prescribing techniques, and they must also account to others such as 
regulators, legislators, and their own boards. As a consequence, the accountability processes that follow should give contributors the information they need in order to be held accountable. Most funders seek similar information or guarantees that funds will be utilized in accordance with the conditions of the request. Funders may form a sector to coordinate their reporting obligations, enabling NGOs with many funders to submit a single report to several authorities. Some funders are beginning to investigate this issue. The flexibility of the donor community may help in ensuring that accountability measures set for the donor also serve as learning mechanisms for the NGO.

One criterion that may be utilized is an accountability system's ability to serve more than one stakeholder. As previously stated, solidarity in literacy has developed into one that simultaneously benefits a number of stakeholders. The vast majority of non-governmental organizations (NGOs) want to measure their impact, demonstrate their effectiveness, and account for their actions. Donor organizations should encourage accountability processes that benefit a wide range of stakeholders, including the NGO's own internal learning requirements. Exploring a company's donors or NGO's flaws is disturbing. An unbiased assessor is the best individual to determine the actual symbiotic relationship between donor and NGO.

\section{Conclusion}

In the world of non-profits, accountability is a very elusive concept. As a result, it is unlikely that a single measure of probity and accountability can be established. It is important to see the issue of responsibility in nonprofits as a chronic illness that requires treatment. Multiple variables influence the degree to which responsibility may be assessed. The reasons why NGOs were created will probably give us a sense of who they should answer to. Accountability is approached differently as studied by the two NGOs. This shows the significance of NGO values by encouraging ethical conduct on the ground and in the execution of responsibilities. However, there are differences in how both NGOs see accountability in connection to their achievements and poverty reduction goals. Due to the NGO's mission, officials at Global Family Network Ghana (GFNG) are held to a higher level of responsibility. The study revealed that Global Family Network Ghana (GFNG) is funded by individual voluntary donations (sponsors). The development mission of poverty reduction is seen in the backdrop. As long as specific accountability procedures exist, officers seem to be more motivated to fulfill accountability requirements by their convictions. The Network for Rural Human Resource Development and Enterprise Initiative, on the other hand, is in a different position. The study found that certain values seem to be hidden in the realm of development. However, in the framework of the Network for Rural Human 
Resource Growth and Enterprise Initiative, whose funding is provided by contractual secular donors, accountability for the beneficiaries' development is considered irrelevant in the eyes of the donors. Accountability to donors is simply a measurable report on how donor funds are being used and progressing toward sustainable development.

The analysis of interviews and documentary material showed the NGOs' accountability links, as well as their unique habits in the field, where they operate as development agents in communities and rural areas. However, there are certain limitations in terms of client responsibility, due in part to rivalry in the development industry as a result of donor financing for projects. In other words, non-governmental organizations (NGOs) have limits in their attempts to help the poor and needy in society. As a consequence, it is recommended that donors show a much greater commitment to accountability and actively involve beneficiaries in the process of obtaining genuine benefits.

\section{References:}

1. Adei (2015). The impact of Christianity on national development with special reference to the role of Pentecostalism. Retrieved from: http://cacihq.org/wp-content/uploads/2015.

2. Agyemang, G., Awumbila, M., Unerman, J. \& O'Dwyer, B. (2009). NGO accountability and aid delivery. IN ACCA (Ed.) ACCA Research Report. London, Certified Accountants Educational Trust (ACCA)

3. Agyemang, G., O'Dwyer, B., Unerman, J. \& Awumbila, M. (2017). Seeking 'conversations for accountability': mediating the impact of non-governmental organization (NGO) upward accountability processes. Accounting, Auditing and Accountability Journal, 30(5), 15-38

4. Alex, J. \& Wilford, R. (2010). Listen first: A pilot system for managing downward accountability in NGOs, Development in Practice, 20(7):797-811.

5. Andrews, A. (2014). Downward accountability in unequal alliances: Explaining NGO responses to Zapatista demands. World Development, 54, 99-113.

6. Armah, F. A., Yawson, D.O. \& Yengoh, G.T. et al. (2010). Impact of floods on livelihoods and vulnerability of natural resource dependent communities in Northern Ghana. Water, 2(2), 120-139.

7. Assad, M. J. \& Goddard, A. R. (2010). Stakeholder salience and accounting practices in Tanzanian NGOs . International Journal of Public Sector Management, 23 (3), 276-299

8. Awio, G., Northcott, D. \& Lawrence, S. (2011). Social capital and accountability in grassroots NGOs: The case of the Ugandan 
community-led HIV/AIDS initiative. Accounting, Auditing \& Accountability Journal, 24(1), 63-92.

9. Banks, N. \& Hulme, D. (2012). The role of NGOs and civil society in development and poverty reduction. Brooks World Poverty Institute Working Paper171, Manchester: University of Manchester.

10. Baur, D. \& Schmitz, H. P. (2012). Corporations and NGOs: When accountability leads to co-optation. Journal of Business Ethics, 106(1): 9-21.

11. Bawole, J. N. \& Langnel, Z. (2016). Downward accountability of NGOs in community project planning in Ghana. Development in Practice, 26(7), 920-932.

12. Behn, R. D. (2001). Rethinking democratic accountability. Washington D.C.: The Brookings Institution.

13. Bendell, J. (2006). Debating NGO accountability. New York and Geneva: UN-NGLS

14. Bob-Millar, George, M. \& Bob-Milliar, Gloria, K. (2007, Ghanaweb.com). Christianity in the Ghanaian State in the Past Fifty Years. Retrieved from:

https://www.ghanaweb.com/GhanaHomePage/features/ChristianityIn-The-Ghanaian-State-In-The-Past-Fifty-Years-119921

15. Boehle, J. (2010). Religious NGOs at the UN and the Millennium Development Goals: An introduction. Global Change, Peace \&Security, 22(3),275-296.

16. Bourdieu, P. \& Wacquant, L. (1992). An invitation to reflexive sociology. Chicago, IL: University of Chicago Press; Cambridge: Polity Press.

17. Bourdieu, P. (1989). Social space and symbolic power. Sociological theory, 7(1), 14-25.

18. Bradley, T. (2009). A call for clarification and critical analysis of the work of faith-based development organizations (FBDO). Progress in Development Studies, 9(2), 101-114.

19. Brinkerhoff, J., Smith, S.C. \& Teegen, H. (2007). NGOs and the millennium development goals: Citizen Action to Reduce Poverty. New York: Macmillan.

20. Brown, L.D. \& Kalegaonkar, A. (2002). Support organizations and the evolution of the NGO sector. Nonprofit and Voluntary Sector Quarterly, 31(2), 231-258.

21. Casely-Hayford, L. \& Hartwell, A. (2010). Reaching the underserved with complementary education: lessons from Ghana's state and nonstate sectors. Development in Practice, 20(4-5),527-539. 
22. Christensen, R. A. \& Ebrahim, A. (2006). How does accountability affect mission? The case of a non-profit serving immigrants and refugees. Nonprofit Management and Leadership, 17(2), 195-209.

23. Clarke, G. \& Jennings, M. (2008). Development, civil society and faith-based organizations: Bridging the sacred and the secular. Basingstoke, UK \& New York, NY: Palgrave Macmillan.

24. Dixon, R., Ritchie, J. \& Siwale, J. (2006). Microfinance: accountability from the grassroots. Accounting, Auditing \& Accountability Journal, 19(3), 405-427.

25. Edwards, M. (2000). NGO rights and responsibilities: A new deal for global governance, London: The Foreign Policy Centre.

26. Edwards, M. \& Hulme, D. (1996). Too close for comfort? The impact of official aid on non-governmental organizations. World Development, 24(6): 961-973.

27. Ebrahim, A. \& Weisband, E. (2007). Introduction: Forging Global Accountabilities. In

28. Ebrahim, A. \& Weisband, E. (Eds.), Global Accountabilities. Participation, Pluralism and Public Ethics. Cambridge: Cambridge University Press

29. Ebrahim, A. (2009). Placing the normative logics of accountability in "thick" perspective. American Behavioral Scientist, 52(6), 885-904.

30. Ebrahim, A. (2005). NGOs and organizational change: Discourse, reporting, and learning. Cambridge University Press.

31. Ebrahim, A. (2003a). Making sense of accountability: conceptual perspectives for northern and southern nonprofits. Nonprofit Management and Leadership, 14(2), 191-212

32. Ebrahim, A. (2003). Accountability in practice: Mechanisms for NGOs. World Development, 31(5),813-829.

33. Ebrahim, A. (2002). Information struggles: the role of information in the reproduction of NGO-funder relations. Nonprofit and Voluntary Sector Quarterly, 31(1), 85-113

34. Ferris, E. (2005). Faith-based and secular humanitarian organizations. International review of the RedCross, 87, 311-325.

35. Fowler, A. (2013). Striking a balance: A guide to enhancing the effectiveness of non-governmental organisations in international development. London: Routledge.

36. Ghana Statistical Service (2014). Poverty Profile in Ghana (20052013): Ghana Living Standards Survey Round 6 (GLSS 6) Accra.

37. Ghana Statistical Services (2013). 2010 Population and housing census: National analytical Report [Online]. Retrieved from: http://www.statsghana.gov.gh/docfiles/2010phc/National_Analytical _Report.pdf. 
38. Gibelman, M. \& Gelman, S. R. (2001). Very public scandals: Nongovernmental organizations in trouble. Nonprofit and Voluntary Sector Quarterly, 12(1): 49-66.

39. Golsorkhi, D., Rouleau, L., Seidl, D. \& Vaara, E. (Eds.) (2010). Cambridge handbook of strategy as practice. Cambridge: Cambridge University Press.

40. Government of Ghana (2015). Report on rationalizing social protection in Ghana. Technical Notes. Accra: MoF-MoGCSP\& GSOP.

41. Gray, R. H., Bebbington, J. \& Collison, D. (2006). NGOs, civil society and accountability: Making the people accountable to capital. Accounting, Auditing and Accountability Journal, 19(3), 319-348.

42. Gray, R., Dey, C., Owen, D., Evans, R. \& Zadek, S. (1997). Struggling with the praxis of social accounting: Stakeholders, Accountability, Audits and Procedures. Accounting, Auditing \& Accountability Journal, 10(3), 324-64.

43. Gray, R., Owen, D. \& Adams, C. (1996). Accounting and accountability: Changes and challenges incorporate and social reporting. London: Prentice-Hall.

44. Hudock, A. (1999). NGOs and civil society: democracy by proxy? Cambridge, MA: Blackwell.

45. Jordan, L. \& Van Tuijl, P. (2006). NGO accountability: politics, principles and innovations. London: Earthscan.

46. Kilby, P. (2006). Accountability for empowerment: dilemmas facing nongovernmental organizations. World Development, 34(6), 951-963

47. Kim, J. (2013). Aid and state transition in Ghana and South Korea. Third World Quarterly, 36(7), 1333-1348.

48. Laughlin, R. (2008). A conceptual framework for accounting for public-benefit entities. Public Money and Management, 28(4), 247254.

49. Laughlin, R. (2004). Putting the record straight: a critique of 'methodology choices and the construction of facts: some implications from the sociology of knowledge'. Critical Perspectives on Accounting, 15(2), 261-277.

50. Llewelyn, S. (2003). What counts as "theory" in qualitative management and accounting research? Introducing five levels of theorizing. Accounting, Auditing \& Accountability Journal, 16(4), 662-708.

51. Mackintosh, M. (1992). Questioning the state. Development Policy and Public Action (61-89). Oxford: Oxford University Press. 
52. MDG National Report (2014). A civil society review of progress towards the Millennium Development Goals in Commonwealth Countries. Retrieved from:

http://commonwealthfoundation.com/wpcontent/uploads/2013/10/M DG\%20Reports\%20New\%20Zealand_FINAL_2.pdf.on 20 August, 2021

53. Mulgan, R. (2003). Holding power to account: accountability in modern democracies. New York: Palgrave MacMillan

54. Mulgan, R. (2000). Comparing accountability in the public and private sectors. Australian Journal of Public Administration, 59(1), 87-97.

55. Najam, A. (1996). NGO accountability: A conceptual framework. Development Policy Review, 14(4):339-354.

56. Nelson, T., Ingols, C., Christian-Murtie, J. \& Myers, P. (2013). Susan Murcott and pure home water: Building a sustainable mission-driven enterprise in Northern Ghana. Entrepreneurship Theory and Practice, 37(4), 961-979.

57. O'Dwyer, B. \& Unerman, J. (2008). The paradox of greater NGO accountability: A case study of Amnesty Ireland. Accounting, Organizations and Society, 33(7), 801-824.

58. O'Dwyer, B. (2007). The Nature of NGO Accountability: Motives, Mechanisms and Practice.

59. Unerman, J., Babington, J. \& O O'Dwyer, B. (eds). SustainabilityAccounting and Accountability (Abingdon: Routledge).

60. OECD (2012). Rio+20 outcome document: The future we want. Retrieved from:

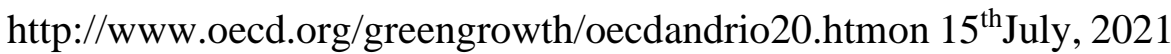

61. Perera, J. (1997). In unequal dialogue with donors: the experience of the Sarvodaya Shramadana Movement. In Hulme, D. \& Edwards, M. (Eds.), NGOs, states and donors: too close for comfort? New York: St. Martins Press in association with The Save the Children Fund.

62. Powell, W.W. \& DiMaggio, P. J. (Eds.) (2012). The new institutionalism in organizational analysis. Chicago: University of Chicago Press.

63. Rahaman, A. S. (2010). Critical accounting research in Africa: Whence and whither. Critical Perspectives on Accounting, 21(5), 420427.

64. Riddel, R. C. (1999). Evaluating NGO development interventions. In Lewis, D. (Ed.),International per-spectives on voluntary action: reshaping the Third Sector 222-241. London: Earthscan.

65. Roberts, J. (1991). The possibilities of accountability. Accounting, Organizations and Society, 16(4),355-368. 
66. Stewart, J. D. (1984). The role of information in public accountability. Issues in Public Sector Accounting, 17, 13-34.

67. Unerman, J. \& O'Dwyer, B. (2006a). On James Bond and the importance of NGO accountability. Accounting, Auditing and Accountability Journal, 19(3), 305-318.

68. Woolnough, B. E. (2011). Christian NGOs in relief and development: One of the church's arms for holistic mission. Transformation: An International Journal of Holistic Mission Studies, 28(3), 195-205.

69. Woolnough, B. E. (2013). Good news from Africa, community transformation through the church. Transformation: An International Journal of Holistic Mission Studies, 35(3), p.0265378813501740.

70. Young, D. R., Bania, N. \& Bailey, D. (1996). Structure and accountability: a study of national nonprofit associations. Nonprofit Management and Leadership, 6(4), 347-365. 